\title{
SUPERVISI AKADEMIK DAN KOMITMEN KERJA GURU TERHADAP KINERJA MENGAJAR GURU
}

\author{
Oleh: \\ Susana \\ Yayasan Trinitas \\ (email: srsusandp@gmail.com )
}

\begin{abstract}
ABSTRAK
Penelitian ini bertujuan untuk mendeskripsikan, menganalisis dan menguji kebermaknaan kontribusi supervisi akademik dan komitmen kerja guru terhadap kinerja mengajar guru SD Yayasan Penyelenggaraan Ilahi Indonesia (YPII). Metode penelitian ini menggunakan metode deskriptif dengan pendekatan penelitian kuantitatif melalui survei. Pengolahan data menggunakan statistik meliputi analisis regresi linier/ganda, analisis korelasi, dan analisis determinasi.Populasi penelitian adalah guru SD se-YPII berjumlah 130 dengan sampel sebanyak 104 orang. Hasil penelitian dari penelitian ini meujukkan bahwa Kinerja Mengajar Guru SD YPII dipengaruhi oleh supervisi dan komitmen sebesar (36,20\%), Supervisi Akademik berkontribusi signifikan dan positif terhadap Kinerja Mengajar Guru dengan kategori cukup, sebesar (27,20\%), Komitmen Kerja Guru berkontribusi positif dan signifikan terhadap Kinerja Mengajar Guru dengan kategori cukup, sebesar $(30,60 \%)$.
\end{abstract}

Kata Kunci: Kinerja Mengajar Guru, Komitmen Kerja Guru, Supervisi Akademik.

\begin{abstract}
The aims of this research are to describe, analyze and test the meaningful contribution of academic supervision and teachers work commitment to elementary school teachers teaching performance of Yayasan Penyelenggaraan Ilahi Indonesia (YPII). The samples of this research are 104 out of 130 elementary school teachers of YPII as the population of the study. This research was conducted in quantity approach and descriptive method using survey technique. The data are tabulated covering linear regression, correlation analysis, and determination analysis. The findings of the research show that 1) elementary school teachers teaching performance of Yayasan Penyelenggaraan Ilahi Indonesia (YPII) is affected by supervision and commitment as much as $36.20 \%$,2) academic supervision has significant and positive contribution to teachers teaching performance as much as $27.20 \%$.3) teacher working commitment has significant and positive contribution as much as $30.60 \%$.
\end{abstract}

Key words: Academic Supervision, Teachers Teaching Performance, Teachers Work Commitment

\section{PENDAHULUAN}

Salah satu cara mengukur keberhasilan pendidikan nasional dalam mengembangkan kualitas peserta didiknya adalah dengan mengukur kualitas para pendidik atau kualitas para gurunya. Donni Joni Priansa (2014, hlm. 79) menyebutkan tingkat keberhasilan guru dalam melaksanakan dan menyelesaikan pekerjaan utamanya sebagai guru adalah level kinerja atau "level of performance". Faktor lain yang memengaruhi kinerja guru adalah konsistensi monitoring dalam hal ini supervisi guru.. Sergiovanni (dalam Daryanto, 2015, hlm. 194) menegaskan bahwa refleksi praktis penilaian unjuk kerja guru dilakukan melalui supervisi akademik.

Robbins (dalam Juwita H R, 2013, hlm. 79) menyebutkan kinerja merupakan fungsi dari Ability (A), motivation (M) dan opportunity (O). Jelas bahwa ability dan motivation merupakan faktor yang berasal dari dalam diri seseorang, sedangkan opportunity merupakan faktor dari luar diri seseorang. Pendapat senada juga diutarakan oleh Husanker (dalam Usman, 2008, hlm. 145) bahwa kinerja merupakan hasil interaksi dari (ability $\mathrm{X}$ motivation), Ability $=$ (aptitude $\mathrm{X}$ training $\mathrm{X}$ resources $)$, dan Motivation $=($ desire $\mathrm{X}$ commitment)". Maka, kinerja merupakan hasil interaksi dari faktor aptitude (bakat) $\mathrm{X}$ training (latihan) $\mathrm{X}$ resources (sumber daya) $\mathrm{X}$ desire (keinginan) X commitment.

Armstrong \& Baron sebagaimana dikutip Wibowo, (2014, hlm. 84) berpendapat bahwa kinerja seseorang dipengaruhi oleh beberapa faktor yaitu: Personal Factor, ditunjukkan oleh tingkat keterampilan, kompetensi, motivasi, dan komitmen individu. (b) Leadership Factor, ditentukan oleh kualitas dorongan, bimbingan, dan dukungan yang dilakukan manajer dan team leader. (c) Team factors, ditunjukkan oleh kualitas dukungan yang diberikan oleh rekan sekerja. (d) System factors, 
ditunjukkan oleh adanya system kerja dan fasilitas yang diberikan organisasi, dan (e) Contextual/situasional factors, ditunjukkan oleh tingginya tekanan dan perubahan lingkungan internal dan eksternal. Demikian pula Harsey, Balanchard, \& Johnson (dalam Wibowo, 2014, hlm. 85) menyebutkan tujuh faktor yang mempengaruhi kinerja yang dirumuskannya dengan akronim ACHIEVE; "A - Ability (knowledge dan skill), $\mathrm{C}-$ Clatiry (understanding atau role perception), $\mathrm{H}$ - Help (organizational support), I - Incentive (motivation atau willingness), E - Evaluation (coaching dan performance feedback), V - Validity (valid dan legal personnel practices), E - Environment (environmental fit)".
Sementara Sedarmayani (dalam Supardi, 2014, hlm.19) secara spesifik menyebutkan sebelas faktor yang mempengaruhi kinerja guru sebagai pendidik antara lain: (1) Sikap mental meliputi; motivasi kerja, disiplin kerja, dan etika kerja, (2) Pendidikan, (3) keterampilan, (4) manajemen kepemimpinan, (5) tingkat penghasilan, (6) gaji dan kesehatan (7) jaminan social, (8) iklim kerja, (9) sarana prasarana, (10) teknologi, (11) kesempatan berprestasi. Berdasarkan pendapat beberapa tokoh diatas, berikut ini merupakan kesimpulan dari banyak faktor yang memengaruhi kinerja seseorang secara umum dan kinerja mengajar guru khususnya, peneliti menyimpulkannya sebagaimana tampak pada Gambar 1berikut ini:

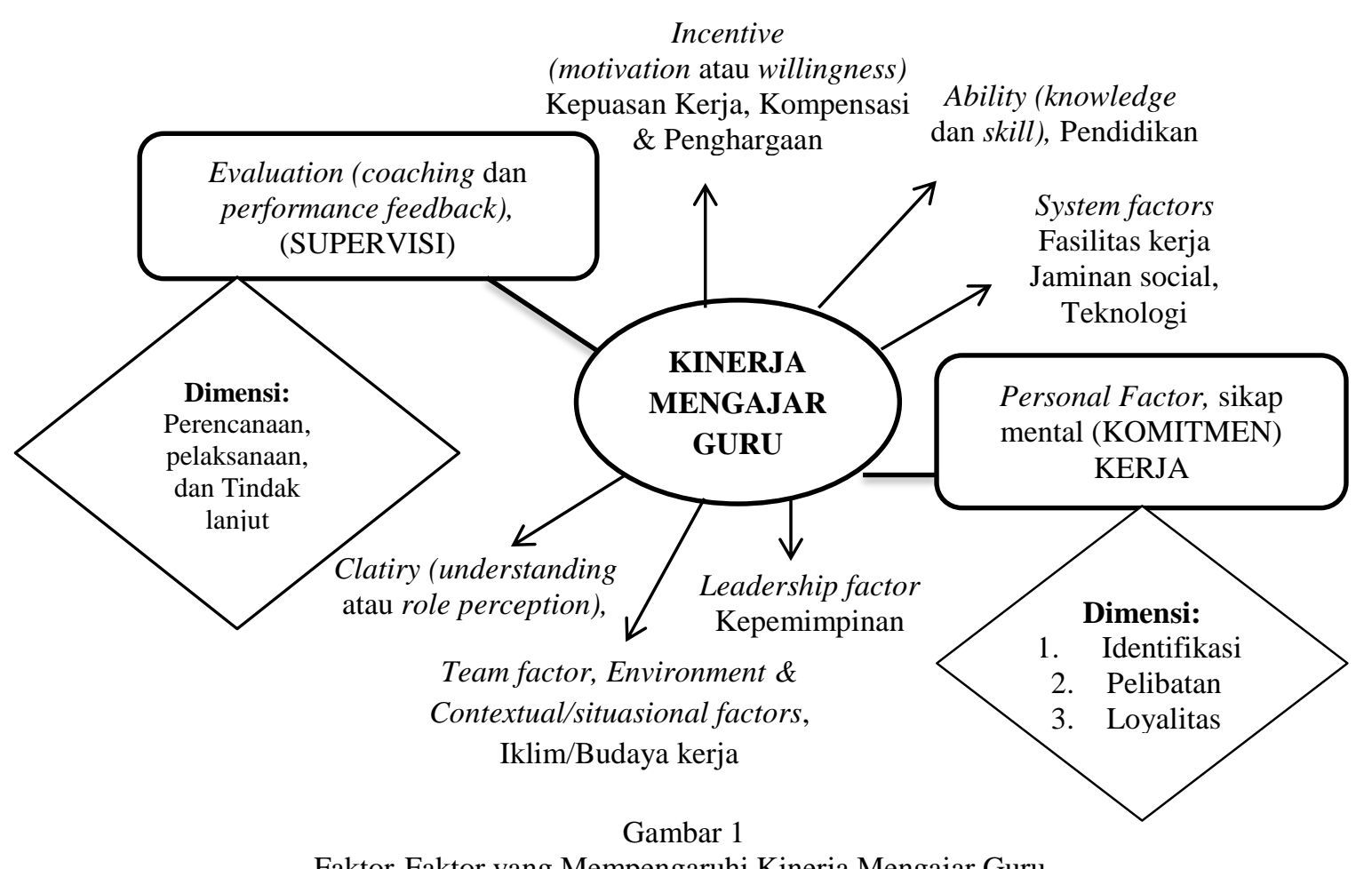

Faktor-Faktor yang Mempengaruhi Kinerja Mengajar Guru.

Sumber: Diadaptasi dari Armstrong \& Baron; Harsey, Balanchard, \& Johnson (dalam Wibowo, 2014 a, 2014 b, hlm. 85), Robbins (dalam Juwita H R, 2013, hlm. 79) dan Sedarmayani (dalam Supardi, 2014, hlm.19)

\section{Kinerja Mengajar Guru}

Kinerja berasal dari istilah performance yang berarti hasil kerja atau prestasi kerja. Secara makna, kinerja sesungguhnya jauh lebih luas dari pada sekedar hasil kerja atau prestasi kerja. Kinerja menyangkut keseluruhan proses bagaimana pekerjaan itu berlangsung. mengemukakan bahwa kinerja sebagai "hasil pekerjaan yang mempunyai hubungan erat dengan tujuan strategis sebuah lembaga, kepuasan konsumen, serta dapat memberikan kontribusi pada ekonom. Singkatnya, kinerja adalah tentang apa dan bagaimana pekerjaan itu dikerjakan sehingga mencapai hasil sebagaimana diharapkan. Berdasarkan pendapat tersebut makin jelas bahwa organisiasi tidak hanya membutuhkan daya pembeda dengan menciptakan keunikan-keunikan dalam menghadapi persaingan ketat, tetapi juga perlu memikirkan dan mempertimbangkan keaneka ragaman kinerja yang dimiliki oleh setiap individu dalam organisasi. Keaneka ragaman kinerja individu merupakan asset terpenting bagi sebuah organisasi dalam menghadapi persaingan. (Amstrong dan Baron dalam Wibowo, 2015, hlm. 7; Sonnentag \& Michael Frese ,2002, hlm. 4)

Terkait kinerja guru, Priansa, (2014, hlm. 78) menyebutkan kinerja sebagai tingkat keberhasilan guru dalam menyelesaikan 
pekerjaannya dengan istilah level of performance atau level kinerja. Kinerja merupakan perwujudan dari kemampuan dalam bentuk karya nyata. Kinerja adalah hasil kerja yang dicapai guru di sekolah dalam rangka mencapai tujuan sekolah atau tujuan pendidikan. Kinerja guru nampak dari tanggung jawabnya dalam menjalankan amanah, profesi yang diembannya, serta moral yang dimilikinya. Hal tersebut tercermin dari sikap kepatuhan, komitmen, dan loyalitasnya dalam mengembangkan potensi peserta didik serta memajukan sekolah. Guru yang memiliki level kinerja tinggi adalah guru yang memiliki produktivitas kerja sama dengan atau di atas standar yang ditentukan demikian sebaliknya.

Kinerja mengajar guru mempunyai spesifikasi tertentu. Kinerja mengajar guru adalah seperangkat perilaku nyata yang ditunjukkan oleh guru pada saat merencanakan, melaksanakan dan menilai hasil pembelajaran. Kinerja mengajar guru sangat penting untuk diperhatikan dan dievaluasi karena guru mengemban tugas profesional yang artinya tugas-tugas keguruan hanya dapat dikerjakan dengan kemampuan khusus yang diperoleh melalui program pendidikan.

\section{Supervisi Akademik}

Supervisi akademik adalah serangkaian kegiatan membantu guru mengembangkan keahliannya mengelola proses pembelajaran demi pencapaian tujuan pembelajaran Glickman (dalam Daryanto, 2015, hlm. 36). Senada dengan pendapat tersebut (Daresh, 1989) menyebutkan bahwa supervisi akademik merupakan upaya membantu guru mengembangkan kemampuannya mencapai tujuan pembelajaran. Pengertian yang hampir sama juga dituliskan oleh Sujana (dalam Daryanto, 2015, hlm. 191) yang menyatakan bahwa supervisi akademik adalah menilai dan membina guru dalam rangka meningkatkan kualitas proses pembelajaran agar kompetensi peserta didik mencapai optimal. Dengan demikian, esensi dari supervisi akademik adalah sama sekali bukan menilai unjuk kerja semata, melainkan membantu guru mengembangkan kemampuan profesionalnya sebagai pelayan pembelajaran.

Meskipun demikian, supervisi akademik tidak bisa terlepaskan dari penilaian unjuk kerja guru dalam mengelola pembelajaran. Apabila dikatakan bahwa, supervisi akademik merupakan serangkaian kegiatan membantu guru mengembangkan kemampuannya mengelola proses pembelajaran, maka menilai unjuk kerja guru dalam mengelola proses pembelajaran merupakan salah satu kegiatan yang tidak bisa dihindarkan prosesnya. Sergiovanni (dalam
Prasojo, 2015, hlm. 84). Penilaian unjuk kerja guru dalam mengelola proses pembelajaran sebagai suatu proses pemberian estimasi kualitas unjuk kerja guru dalam mengelola proses pembelajaran, merupakan bagian integral dari serangkaian kegiatan supervisi akademik.

Alfonso, Firth, dan Neville (dalam Nur Aedi, 2014, hlm. 184) menegaskan bahwa ada tiga konsep pokok dalam pengertian supervisi akademik:

(1) Supervisi akademik harus secara langsung memengaruhi dan mengembangkan perilaku guru dalam mengelola proses pembelajaran. (2) Perilaku supervisor dalam membantu guru mengembangkan kemampuannya harus didesain secara ofisial, sehingga jelas waktu mulai dan berakhirnya program pengembangan tersebut. (3) Tujuan akhir supervisi akademik adalah agar guru semakin mampu memfasilitasi belajar bagi peserta didiknya.

Secara umum supervisi akademik bertujuan untuk membantu guru dalam mengembangkan kemampuannya mencapai tujuan pembelajaran yang dicanangkan bagi muridmuridnya, Glickman (dalam Daryanto, 2015, hlm. 5). Sehingga melalui supervisi akademik diharapkan kualitas akademik yang dilakukan oleh guru semakin meningkat (Daryanto, 2015, hlm. 5). Pengembangan kemampuan dalam konteks ini janganlah ditafsirkan secara sempit, semata-mata ditekankan pada peningkatan pengetahuan dan keterampilan mengajar guru, melainkan juga pada peningkatan komitmen (commitment) atau kemauan (willingness) atau motivasi (motivation) guru, sebab dengan meningkatkan kemampuan dan komitmen kerja guru, kualitas pembelajaran meningkat (Daryanto, 2015, hlm. 38).

Dengan demikian, supervisi akademik yang baik adalah supervisi yang berfungsi untuk mencapai multi tujuan tersebut di atas. Keberhasilan supervisi akademik terjadi apabila semua aspek berfungsi dengan semestinya dan tanpa mengesampingkan tujuan lainnya. Hanya dengan memperhatikan ketiga tujuan supervisi akademik di atas, supervisi dapat berfungsi mengubah perilaku mengajar guru serta meningkatkan kinerjanya sebagai guru profesional dan berdampak nyata bagi peningkatan prestasi peserta didik.

\section{Komitmen Kerja Guru}

Armstrong (2010, hlm. 34) menyebutkan bahwa komitmen sebagai "kecintaan dan kesetiaan yang terdiri dari; (1) penyatuan dengan tujuan dan 
nilai-nilai perusahaan, (2) keinginan untuk tetap bersama/ berada dalam organisasi, (3) kesediaan untuk bekerja keras atas nama organisasi". Sementara Luthans (dalam Wibowo 2015, hlm. 188) mendefinisikan komitmen sebagai: (1) sebuah keinginan kuat untuk tetap menjadi anggota organisasi tertentu, (2) keinginan untuk mendesak usaha pada tingkat atas nama organisasi, (3) keyakinan yang pasti dalam hal tertentu dan penerimaan terhadap nilai-nilai dan tujuan-tujuan organisasi. Dengan kata lain komitmen merupakan sikap yang mencerminkan loyalitas pekerja pada organisasi.

Sedangkan menurut Meyer \& Herscovitch (dalam Aaron Cohen, 2003, hlm. xi) komitmen adalah kekuatan yang mengikat individu untuk suatu tindakan yang relevan dengan satu atau lebih target. Bateman \& Strasser, 1984; Morris \& Sherman, 1981 (dalam Aaron Cohen, 2003, hlm. 18) menyatakan bahwa organisasi yang anggotanya memiliki tingkat komitmen lebih tinggi akan menunjukkan kinerja dan produktivitas yang lebih tinggi pula dengan tingkat absensi dan keterlambatan karyawan rendah. Artinya tingkat komitmen yang dimiliki oleh pekerja mempengaruhi kerja dan pencapaian tujuan organisasi.

Ivancevich, Konopaske, dan Matteson (dalam Wibowo, 2014, hlm. 427) mendefinisikan komitmen sebagai perasaan indentifikasi, pelibatan, dan loyalitas yang dinyatakan oleh pekerja terhadap perusahaan. Menurut mereka, komitmen menyangkut tiga sifat: (a) perasaan identifikasi dengan tujuan organisasi, (b) perasaan terlibat dalam tugas organisasi, dan (c) perasaan loyal pada organisasi. Kemudian, Kreitner dan Kinicki (dalam Wibowo, 2014, hlm. 428), menyebutkan komitmen sebagai sebuah kesepakatan dalam melakukan sesuatu bagi dirinya sendiri, individu lain, dan kelompok/organisasi. Sedangkam komitmen mencerminkan tingkatan keadaan dimana individu mengidentifikasi dirinya pada organisasi dan tujuannya.

Dengan demikian semakin jelas bahwa komitmen organisasi mencakup tiga dimensi utama yaitu; identifikasi dengan tujuan yang akan dicapai oleh organisasi, perasaan pekerja atas keterlibatannya dalam tugas-tugas yang harus diemban dalam organisasi, serta perasaan pekerja atas loyalitas terhadap organisasi. Mengacu pada rumusan tersebut, maka komitmen terhadap organisasi melibatkan 3 (tiga) sikap atau dimensi utama, yaitu: (1) Identifikasi dengan tujuan organisasi; (2) Perasaan keterlibatan dalam tugastugas organisasi; dan (3) Perasaan loyalitas terhadap organisasi. Maka variabel komitmen dapat digunakan sebagai prediktor penting bagi organisasi untuk dapat melihat; apakah seorang pekerja akan dapat bertahan lama dalam organisasi atau hanya akan berubah sementara, untuk selanjutnya akan pindah ke organisasi lain? Jelaslah bahwa komitmen merupakan suatu kondisi dimana para anggota dari sebuah kelompok memberikan upaya, kemampuan, dan loyalitas mereka kepada organisasi dengan harapan akan memperoleh kepuasan dari organisasi.

Komitmen organisasi memiliki beberapa komponen atau tipe seperti affectice commitment, normative commitmen, dan continuance commitment. Masing-masing komponen dipengaruhi oleh faktor yang berbeda-beda. Wibowo (2014, hlm. 431) memberikan penjelasan untuk masing-masing tipe komitmen memiliki faktor yang mempengaruhi berbeda-beda. Affective commitment dipengaruhi oleh berbagai karakteristik personal seperti kepribadian dan locus of control, pengalaman kerja sebelumnya dan kesesuaian nilai. Continuance commitment mencerminkan rasio antara biaya dan manfaat yang berkaitan dengan meninggalkan organisasi. Maka tipe komponen ini dipengaruhi oleh faktor biaya dan manfaat, seperti kurangnya alternatif pekerjaan dan jumlah investasi yang telah dilakukan dalam organisasi atau komunitas tertentu. Sedangkan normatif commitment dipengaruhi oleh proses sosialisasi yang dinamakan psychological contract yang mencerminkan keyakinan pekerja tentang apa yang seharusnya diterima sebagai imbalan atas apa yang mereka telah berikan pada organisasi.

Bonar Hutapea (2012, hlm. 102), dalam penelitiannya tentang dampak negatif dan kerugian yang ditimbulkan apabila seorang guru tidak memiliki komitmen organisasi terhadap sekolah, mengutip Barnes, Crowne, dan Schaefer (2007) yang mengestimasi besarnya kerugian yang ditanggung sekolah dan seluruh sekolah dalam beberapa distrik di Amerika Serikat disebabkan oleh keluar masuknya guru dari sekolah yang satu ke sekolah yang lain, maupun berhentinya guru dari pekerjaannya sebagai guru. Paling tidak 86 juta dolar per tahun terbuang hanya pada sekolah negeri di Chicago saja, belum termasuk resiko yang dialami sekolah yang berakibat pada kinerja sekolah dan prestasi siswa. Hasil penelitian ini memberikan gambaran yang sebenarnya bahwa faktor komitmen sangat menentukan dalam organisasi. Komitmen terhadap organisasi yang tinggi, dapat memberi dampak positif bagi organisasi, yaitu dapat meningkatnya produktivitas.

Bagi pekerja dengan komitmen yang kuat terhadap organisasi, pada umumnya tidak akan 
melakukan pemutusan hubungan kerja untuk mencari dan memperoleh pekerjaan pada organisasi lain sebagaimana diiungkapkan oleh Gibson, Ivancevich \& Donnely, (1997, hlm. 186). Pergantian pekerja yang terlalu sering akan menambah biaya organisasi, yaitu biaya untuk proses penerimaan pekerja baru, biaya promosi, biaya seleksi dan biaya pelatihan yang diperlukan bagi pekerja baru. Di samping itu, pekerja baru umumnya kurang terampil dibandingkan dengan pekerja lama. Maka dengan demikian, biaya untuk monitoring pekerja baru juga akan menjadi lebih besar. Sebaliknya, pekerja dengan komitmen yang kuat terhadap organisasi, dapat menginteraksikan tujuan pribadi dengan tujuan organisasi di mana pekerja tersebut bekerja.

Jingping Sun (2015, hlm. 597) dalam jurnalnya mengungkapkan bahwa "... komitmen guru secara signifikan berhubungan erat dengan hasil belajar siswa". Seorang guru dengan komitmen tinggi akan memiliki kepedulian terhadap tugas, kebutuhan siswa, teman sejawat atau atasan langsung, juga terhadap sekolah dan perubahan. Guru mempunyai komitmen terhadap tugas yang dibebankan kepadanya, termasuk tanggung jawab terhadap bangsa, negara, dan sesama manusia. Dengan demikian seorang guru yang mempunyai komitmen tinggi akan dapat melaksanakan tugasnya dengan sempurna, mulai dari perencanaan hingga sampai pada evaluasi dan penilaian. Dari perencanaan yang tertuang dalam bentuk silabus dan RPP sampai pada penilaian dan evaluasi, bahkan bukan saja hanya sampai pada tugas tetapi lebih pada perkembangan kehidupan kepribadian manusianya yaitu peserta didik.

\section{METODE PENELITIAN}

Metode penelitian; analisis deskriptif, pendekatan kuantitatif, teknik analisis dengan korelasi product moment, determinasi dan regresi dengan menggunakan Software SPSS 20. Pengumpulan data melalui angket. Populasi dalam penelitian ini yaitu guru-guru bahwa guru-guru SD pada YPII yang berada di kota Bandung, Jakarta, dan Semarang, dengan teknik Simple Random Sampling.
Populasi penelitian adalah guru SD se-YPII berjumlah 130 dengan sampel sebanyak 104 orang. Pendekatan penelitian kuantitatif dengan metode deskriptif melalui survei. Pengolahan data menggunakan statistik meliputi analisis regresi linier/ganda, analisis korelasi, dan analisis determinasi.

\section{HASIL PENELITIAN DAN PEMBAHASAN}

\section{Deskripsi Kinerja Mengajar Guru Sekolah Dasar pada YPII}

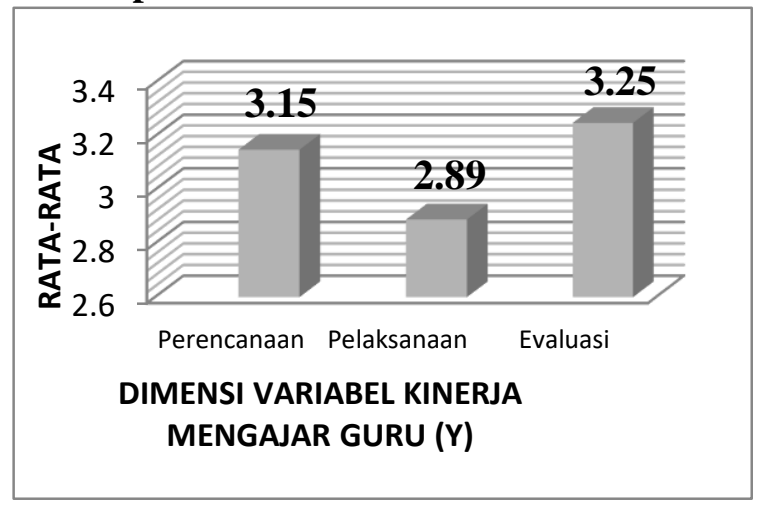

\section{Grafik Kecenderungan Umum Dimensi Kinerja Mengajar Guru SD YPII}

Secara keseluruhan, berdasarkan pengolahan atas jawaban responden untuk variabel Kinerja Mengajar Guru diperoleh skor 3.10 masuk kategori "sangat tinggi". Sedangkan untuk ketiga dimensi variabel, dimensi evaluasi pembelajaran memperoleh skor tertinggi sebesar 3.25, masuk kategori "sangat tinggi", diikuti dimensi perencanaan pembelajaran dengan skor 3.15, masuk kategori "sangat tinggi", sedangkan dimensi pelaksanaan pembelajaran mendapatkan skor terendah sebesar 2,89 masuk kategori "tinggi". Dengan demikian, untuk Kinerja Mengajar Guruguru Sekolah Dasar pada YPII di kota Bandung, Jakarta, dan Semarang dapat disimpulkan bahwa; kinerja mengajar guru khususnya dalam merencanakan pembelajaran, melaksanakan, dan mengevalusai pembelajaran sudah sangat baik. 


\section{Deskripsi Supervisi Akademik Guru Sekolah} Dasar pada YPII

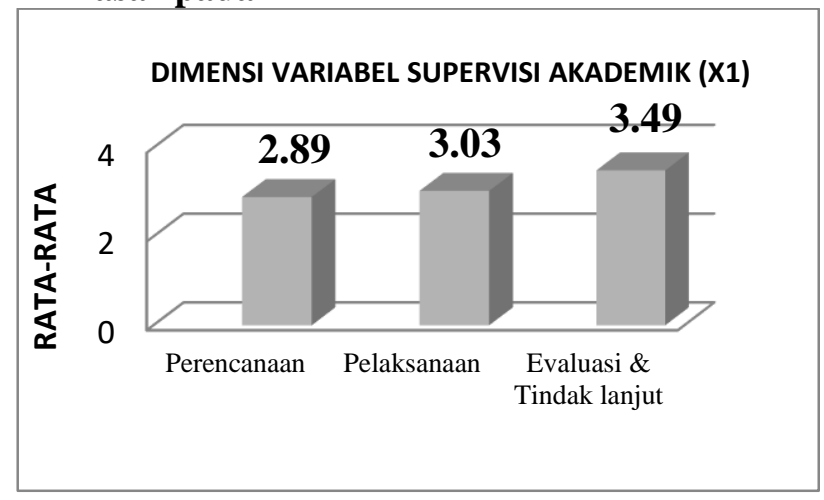

Gambar 6

Grafik Kondisi Umum Dimensi Supervisi Akademik di SD

Secara keseluruhan, dari jawaban responden atas variabel Supervisi Akademik diperoleh skor umum sebesar 3,13 masuk kategori "sangat tinggi". Dari ketiga dimensi supervisi akademik, dimensi tindak lanjut mendapatkan skor tertinggi sebesar 3.49 dengan kategori "sangat tinggi", dimensi pelaksanaan memperoleh skor 3.03, masuk kategori "sangat tinggi", sedangkan dimensi perencanaan menempati posisi terendah dengan skor 2,89 masuk kategori "tinggi". Hal ini mengindikasikan bahwa guru-guru SD pada YPII yang berada di kota Bandung, Jakarta, dan Semarang sudah memiliki pemahaman tentang supervisi akademik dengan sangat baik.

\section{Deskripsi Komitmen Kerja Guru Sekolah Dasar pada YPII.}

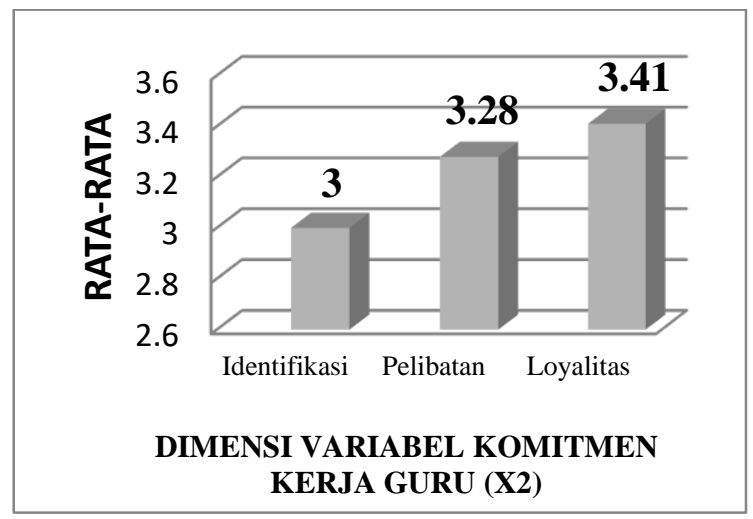

Gambar 7

Grafik Kondisi Umum Dimensi Komitmen Kerja Guru SD pada YPII

Secara keseluruhan, variabel komitmen kerja guru memperoleh skor umum sebesar 3,23 masuk kategori "sangat tinggi". Dari ketiga dimensi variabel komitmen kerja guru, dimensi Loyalitas menduduki skor tertinggi sebesar 3.41 masuk kategori "sangat tinggi", kemudian dimensi pelibatan dengan skor 3.28 masuk kategori "sangat tinggi", dan terakhir adalah dimensi identifikasi dengan skor 3,00 masuk kategori "sangat tinggi". Hal ini mengindikasikan bahwa guru-guru SD pada Yayasan Penyelenggaraan Ilahi Indonesia yang berada di kota Bandung, Jakarta dan Semarang memiliki tingkat komitmen kerja pada tugas yang diembannya dan pada lembaga baik yayasan maupun sekolah berada pada kategori "sangat tinggi”.

4. Kontribusi Supervisi Akademik $\left(X_{1}\right)$ terhadap Kinerja Mengajar Guru Sekolah Dasar pada Yayasan Penyelenggaraan Ilahi Indonesia (Y) di kota Bandung, Jakarta, dan Semarang.

Setelah dilakukan perhitungan koefesian regresi, diperoleh kontribusi supervisi akademik terhadap kinerja mengajar guru dengan rumus berikut: $\hat{Y}=a+b X_{1}$ atau $\hat{Y}=49.996+0.374 X_{1}$ dengan nilai koefisien korelasi sebesar 0,521. Koefisien b merupakan koefisien arah regresi yang menyatakan perubahan rata-rata variabel $\mathrm{Y}$ untuk setiap perubahan variabel $X$ sebesar satu satuan. Perubahan ini merupakan pertambahan bila $b$ bertanda positif dan penurunan bila $b$ bertanda negatif. Dari persamaan tersebut diatas dapat diterjemahkan bahwa:

- Nilai konstanta sebesar 49.996 menyatakan bahwa jika tidak ada nilai Supervisi Akademik maka nilai Partisipasi sebesar 49.996

- Koefisien regresi X sebesar 0,521 bernilai positif. Nilai tersebut menyatakan bahwa setiap adanya penambahan satu nilai supervisi akademik maka nilai Partisipasi akan bertambah sebesar 0,521.

Dari persamaan regresi tersebut dapat diinterprestasikan bahwa jika variabel supervisi akademik $\left(\mathrm{X}_{1}\right)$ dengan kinerja mengajar guru $(\mathrm{Y})$ diukur dengan menggunakan instrumen yang dikembangkan dalam penelitian ini, maka setiap perubahan skor supervisi akademik sebesar satu satuan dapat diestimasikan skor kinerja mengajar guru akan berubah sebesar 0.521 satuan kearah yang sama. Dengan demikian dapat disimpulkan bahwa makin efektif supervisi akademik maka makin tinggi pula kinerja mengajar guru. Demikian sebaliknya, semakin tidak efektif supervisi akademik maka akan semakin rendah kinerja mengajar guru.

Selanjutnya hasil perhitungan koefisien determinansi dengan menggunakan SPSS, diketahui besarnya koefisien determinansi variabel 
Supervisi Akademik $\left(\mathrm{X}_{1}\right)$ terhadap variabel Kinerja Mengajar Guru (Y) adalah Rsquare atau $\mathrm{R}^{2} \mathrm{yx} 1 \mathrm{x} 2$ $=0,521=27,20 \%$ dan besarnya pengaruh variabel lain $=1-(\mathrm{R})^{2}=1-(0,521)^{2}=0,728$ atau $72,80 \%$. Artinya, kontribusi Supervisi Akademik terhadap Kinerja Mengajar Guru sebesar 27,20\% sedangkan sisanya sebesar $72,80 \%$ dipengaruhi oleh faktor lain. Hal ini berarti bahwa kontribusi supervisi akademik termasuk dalam kategori "cukup" dalam rangka peningkatan kinerja mengajar guru SD pada YPII.

Dari hasil penelitian yang dilakukan, dapat ditarik kesimpulan bahwa semakin efektif supervisi akademik semakin tinggi tingkat kinerja mengajar guru. Demikian pula sebaliknya, semakin tidak efektif supervisi akademik, semakin rendah pula kinerja mengajar guru. Maka, kegiatan supervisi akademik merupakan faktor yang cukup berpengaruh bagi peningkatan kinerja mengajar guru.

\section{Kontribusi Komitmen Kerja Guru $\left(\mathbf{X}_{2}\right)$ terhadap Kinerja Mengajar Guru Sekolah Dasar pada Yayasan Penyelenggaraan Ilahi Indonesia (Y) di kota Bandung, Jakarta, dan Semarang.}

Berdasarkan hasil perhitungan koefisien regresi dengan rumus $\hat{Y}=\mathrm{a}+\mathrm{bX}_{2}$ atau $\hat{\mathrm{Y}}=38,130$ $+0.514 \mathrm{X}_{2}$ dengan nilai koefisien korelasi sebesar 0,553. Di mana, koefisien b dinamakan koefisien arah regresi yang menyatakan perubahan rata-rata variabel $\mathrm{Y}$ untuk setiap perubahan variabel $\mathrm{X}$ sebesar satu satuan. Perubahan ini merupakan pertambahan bila $\mathrm{b}$ bertanda positif dan penurunan bila $b$ bertanda negatif. Dari persamaan tersebut di atas dapat dijelaskan sebagai berikut:

- Konstanta sebesar 38,130 menyatakan bahwa jika tidak ada nilai Komitmen Guru, maka nilai Partisipasi sebesar 38,130.

- Koefisien regresi X sebesar 0,514 menyatakan bahwa setiap penambahan satu nilai komitmen guru, maka nilai partisipasi bertambah sebesar 0,514.

Berdasarkan hasil persamaan regresi $\mathrm{Y}$ atas $\mathrm{X}_{2}$, maka $\hat{\mathrm{Y}}=38,130+0.514 \mathrm{X}_{2}$. Dengan demikian dapat diinterprestasikan bahwa jika variabel komitmen guru $\left(\mathrm{X}_{2}\right)$ dengan kinerja mengajar guru (Y) diukur dengan instrumen yang dikembangkan dalam penelitian ini, maka setiap perubahan skor Komitmen Guru sebesar satu satuan dapat diestimasikan skor Kinerja Mengajar Guru akan berubah sebesar 0.514 satuan pada arah yang sama.

Sedangkan dari hasil perhitungan dengan bantuan SPSS untuk nilai koefisien determinansi variabel Komitmen Guru $\left(\mathrm{X}_{2}\right)$ terhadap Kinerja Mengajar Guru (Y) diketahui Rsquare atau $\mathrm{R}^{2} \mathrm{yx} 1 \mathrm{x} 2=0,553=30,60 \%$ dan besarnya kontribusi variabel lain $=1-(\mathrm{R})^{2}=1-(0,553)^{2}=$ 0,694 atau $69,40 \%$. Artinya kontribusi Komitmen Guru terhadap Kinerja Mengajar Guru sebesar $30.60 \%$ sedangkan selebihnya sebesar $69,30 \%$ dipengaruhi oleh faktor lain yang tidak diteliti dalam penelitian ini. Makna koefisien determinansi variabel Komitmen Guru $\left(\mathrm{X}_{2}\right)$ terhadap Kinerja Mengajar Guru sebesar 30,60\% dengan koefesien korelasi sebesar 0,514 yang menunjukkan bahwa adanya kontribusi dalam kategori sedang (cukup) dan positif. Hasil penelitian untuk ini menunjukkan bahwa kinerja mengajar guru akan meningkat apabila komitmen guru bertambah. Dengan demikian komitmen kerja guru Sekolah Dasar pada Yayasan penyelenggaraan Ilahi Indonesia berada pada kategori cukup sedang.

Dari uraian di atas dapat ditarik kesimpulan bahwa semakin tinggi komitmen kerja guru, semakin tinggi pula tingkat kinerja mengajar guru. Demikian pula sebaliknya, semakin rendah komitmen kerja guru, semakin rendah pula kinerja mengajar guru.

6. Kontribusi Supervisi Akademik ( $\left.X_{1}\right)$ dan Komitmen Guru $\left(\mathbf{X}_{2}\right)$ terhadap Kinerja Mengajar Guru Sekolah Dasar pada Yayasan Penyelenggaraan Ilahi Indonesia (Y) di kota Bandung, Jakarta, dan Semarang.

Berdasarkan perhitungan regresi dengan rumus $\hat{Y}=a+b X_{1}+b X_{2}$ atau $\hat{Y}=33,083+0,212 X_{1}$ $+0,349 \mathrm{X}_{2}$, dapat diinterprestasikan bahwa jika variabel Supervisi Akademik $\left(\mathrm{X}_{1}\right)$ dan variabel Komitmen kerja guru $\left(\mathrm{X}_{2}\right)$ dengan Kinerja Mengajar Guru ( $\mathrm{Y}$ ) diukur dengan instrumen yang dikembangkan dalam penelitian ini, maka setiap perubahan skor Supervisi Akademik dan Komitmen kerja Guru sebesar satu satuan dapat diestimasikan skor Kinerja Mengajar Guru akan berubah sebesar 0,376 satuan dan 0,295 satuan pada arah yang sama. Artinya semakin efektif supervisi akademik dilakukan, maka semakin tinggi komitmen kerja guru, dengan demikian semakin tinggi pula tingkat kinerja mengajar guru SD pada YPII.

Selanjutnya, berdasarkan perhitungan koefisien determinansi variabel Supervisi Akademik (X1) dan variabel Komitmen Guru (X2) secara bersama-sama terhadap variabel Kinerja Mengajar Guru (Y) diperoleh koefisien determinan $\mathrm{R}$ square atau $\mathrm{R}^{2} \mathrm{yx} 1 \mathrm{x} 2=0,602=36,20 \%$ dan besarnya kontribusi variabel lain $=1-(\mathrm{R})^{2}=1-$ 
$(0,602)^{2}=0,638$ atau $63,80 \%$. Artinya variabel Supervisi Akademik dan Komitmen kerja Guru berkontribusi secara bersama-sama terhadap kinerja mengajar guru sebesar $36,20 \%$ sedangkan sisanya sebesar $63,80 \%$ dipengaruhi oleh faktor lain yang tidak diteliti dalam penelitian ini.
Selanjutnya berdasarkan temuan empiris di atas, menunjukkan adanya pengaruh yang positif dan signifikan antara variabel supervisi akademik dan variabel komitmen guru secara bersama-sama terhadap kinerja mengajar guru.

\section{SIMPULAN DAN REKOMENDASI}

Belum optimalnya kinerja mengajar guru SD diatas perlu ditindak lanjuti dengan kegiatan supervisi. Pada variabel supervisi akademik terdapat tiga dimensi yang diteliti yaitu, dimensi perencanaan supervisi, dimensi pelaksanaan supervisi, dan dimensi tindak lanjut. Dari ketiga dimensi supervisi tersebut, dimensi tindak lanjut mendapatkan skor tertinggi dengan kategori sangat tinggi, sementara dimensi perencanaan memperoleh skor terendah dengan kategori tinggi. YPII sudah memiliki instrumen supervisi dengan item-item yang sangat familiar. Namun, karena kesibukan Kepala Sekolah, dan wakasek bagian kurikulum maka kegiatan supervisi kurang terjadwal secara rutin. Kegiatan supervisi dilaksanakan ketika ada kebutuhan seperti: akreditasi sekolah, penilaian kinerja guru oleh dinas pendidikan, dan ketika ada permasalahan yang timbul dari guru tertentu. Selain itu, minimnya tingkat pemahaman guru tentang supervisi juga turut memengaruhi.

Pada variabel komitmen kerja guru dimensi loyalitas dan pelibatan berada pada kategori sangat tinggi, sedangkan dimensi identifikasi mendapat skor terendah dengan kategori tinggi. Ada banyak faktor yang menyebabkan rendahnya rasa identifikasi guru pada sekolah. Rendahnya komitmen kerja guru juga ditunjukkan melalui keterlambatan guru hadir di sekolah. Selain itu, kesiap sediaan guru untuk membimbing siswa kurang mampu dalam pembelajaran juga rendah, serta ada kecenderungan guru ingin cepat-cepat meninggalkan sekolah. Faktor lain beasal dari lembaga yaitu belum adanya sistem internalisasi visi dan misi sekolah/Yayasan bagi guru-guru YPII.

Secara bersama-sama terdapat kontribusi positif dan signifikan supervisi akademik dan komitmen kerja guru terhadap kinerja mengajar guru pada Yayasan Penyelenggaraan Ilahi Indonesia. Dengan demikian supervisi akademik dan komitmen kerja guru memberikan sumbangan terhadap peningkatan kinerja mengajar guru. Peningkatan intensitas supervisi akademik dan penguatan komitmen kerja guru akan diikuti dengan peningkatan kinerja mengajar guru. Artinya supervisi akademik dan komitmen kerja guru secara bersama-sama menjadi faktor yang dapat menentukan tinggi rendahnya kinerja mengajar guru YPII. Semakin efektif kegiatan supervisi akademik semakin tinggi level kinerja mengajar guru. Demikian juga semakin tinggi komitmen kerja guru semakin tinggi pula tingkat kinerja mengajar guru. Tentu saja semakin efektif supervisi akademik, semakin tinggi komitmen kerja guru, semakin tinggi pula tingkat kinerja mengajar guru SD pada YPII.

\section{DAFTAR PUSTAKA}

Aaron Cohen. (2003). Multiple Commitments in the Workplace An Integrative Approach. London: Lawrence Erlbaum Associates, Publishers.

Armstrong Michael. (2010). Managing People A Practical Guide For Line Managers. London: Kongan Page Limited 120 Pentoville Road.

Bonar Hutapea. (2012). Sifat-kepribadian dan dukungan organisasi sebagai prediktor komitmen organisasi guru pria di sekolah dasar. Jurnal Makara Sosial Humaniora. Vol. 16, No. 2, hal 101-115.

Daresh. (1989). Supervision as Aproactive Process. New Jersey: Longman.
Daryanto. (2013). Standar Kompetensi dan penilaian Kinerja Guru Profesional. Yogyakarta: Gava Media.

Daryanto., Tutik Rachmawati. (2015). Supervisi Pembelajaran. Yogyakarta: Gava Media.

Gibson,J.I. Ivanceviek JM. Dan Donnelly, JH, (1997). Organisasi. Terjemahan Nunuk Adiarni, Jakarta: Bina Rupa.

Jingping Sun, (2015). Conceptualizing the critical path linked by teacher commitment. Journal of Educational Administration. Vol. 53 Iss 5 pp. $597-624$.

Juwita RH. (2013). Pengaruh Pendidikan Pelatihan KTSP dan Kompetensi Terhadap Kinerja Mengajar Guru SMPN di Kecamatan 
Sumedang Selatan. Jurnal Administrasi Pendidikan. UPI. Vol. XVII No. 1 hal. 7383.

Nur Aedi. (2014). Pengawasan pendidikan. Tinjauan Teori dan Praktek. Jakarta: Rajagrafindo Persada.

Prasojo dan Sudiyono. (2015). Supervisi Pendidikan. Yogyakarta: Gava Media.I

Priansa, Donni Juni. (2014). Kinerja Profesionalisme Guru. Bandung: Alfabeta

Sonnentag, Sabine dan Michael Frese. (2002). Performance Concepts and Performance Theory. Psychological Management of
Individual Performance. Edited by Sabine Sonnentag. C 2002 John Wiley \& Sons, Ltd.

Supardi. (2014). Kinerja Guru. Jakarta: RajaGrafindo Persada.

Usman. (2008). Menjadi Guru Profesional. Bandung: Remaja Rosdakarya.

Usman. (2014). Manajemen Teori, Praktik, dan Riset Pendidikan. Jakarta: Bumi Aksara.

Wibowo. (2014). Manjemen Kinerja. Jakarta: RajaGrafindo Persada.

Wibowo. (2015). Perilaku dalam Organisasi. Jakarta RajaGrafindo Persada. 